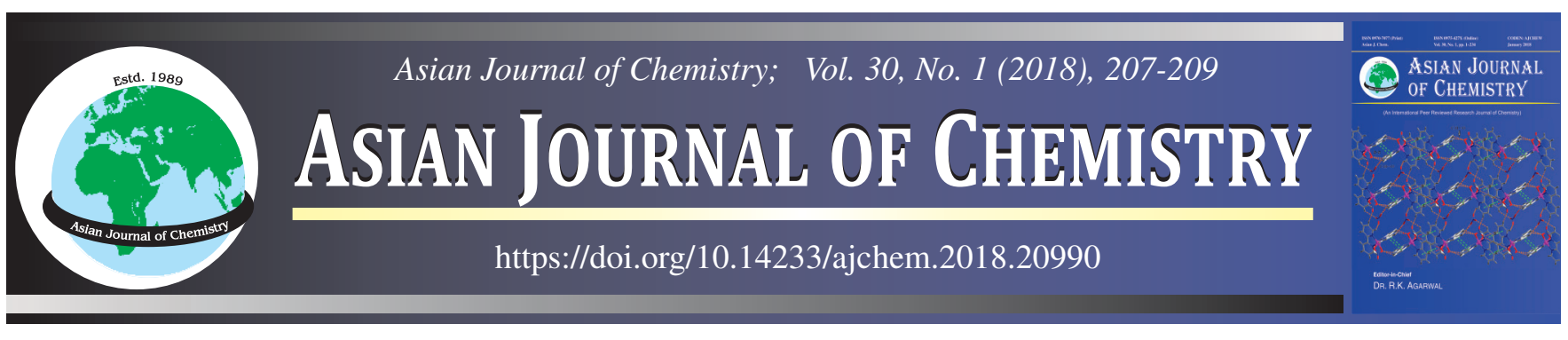

\title{
Adsorption and Photodegradation of Methylene Blue by Allophane and Nanocomposite Bismuth Oxyiodide-Allophane
}

\author{
Nur A. Limatahu ${ }^{1, *}$, Indra Cipta ${ }^{1}$, St. Hayatun Nur Abu $^{1}$, Indriana Kartini ${ }^{2}$ and Yateman Arryanto ${ }^{2}$
}

${ }^{1}$ Department of Chemistry Education, Khairun University, Ternate, North Maluku, Indonesia

${ }^{2}$ Department of Chemistry, Faculty of Mathematics and Natural Science, Universitas Gadjah Mada, Yogyakarta, Indonesia

*Corresponding author: E-mail: nurlimatahu29@gmail.com

Received: 21 August 2017;

Accepted: 23 October 2017;

Published online: 30 November 2017;

AJC-18677

\begin{abstract}
This study examines the ability of allophane as an adsorbent and photocatalytic capability of nanocomposite bismuth oxyiodide (BiOI)allophane in removal of methylene blue dye. Adsorption was performed by using $50 \mathrm{mg}$ of allophane from volcanic soil of mount Gamalama. The adsorption results showed that the optimum contact time is $10 \mathrm{~min}$ with adsorption percentage $91.81 \%$. The percentage of adsorption decreases with increasing contact time and reaches equilibrium at about in $120 \mathrm{~min}$. The initial concentration of methylene blue has an effect on the adsorption percentage. This is evidenced by the increased adsorption percentage of $73.35,78.78,82.12,87.81 \%$, respectively for concentrations of $20,50,80$ and $100 \mathrm{ppm}$. The photodegradation test results showed an excellent photocatalytic ability of BiOI-allophane composites. Using direct sunlight for $45 \mathrm{~min}$, the percentage of photodegradation is $99.46 \%$. Increased contents of allophane in BiOI-allophane nanocomposite increases the photocatalytic ability.
\end{abstract}

Keywords: Methylene Blue, Adsorption, Photodegradation, Allophane, Bismuth oxyiodide, Nanocomposite.

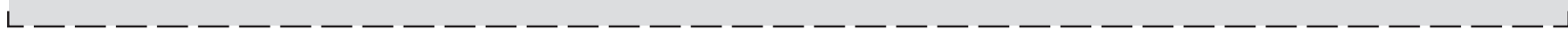

\section{INTRODUCTION}

The rapidly growing industrial development has an effect on the quality of the environment. In the process of industries produce pollutants that can degrade environmental quality. One of the environmental pollutants comes from dye waste of textile industry. Methylene blue is considered as carcinogenic, mutagenic and non-biodegradable because of the presence of benzene groups which is difficult and need a longer time for degradation [1-3]. Hence, it is necessary to decompose first before being discharged into waters $[4,5]$.

The textile industry uses only about $5 \%$ dye in the process, while the remaining $95 \%$ will be wasted as dye wastes [6]. Several methods have been studied to overcome methylene blue contaminants, such as adsorption and photodegradation. Adsorption is the simplest and most frequently used method in industry because it is easy to operate and low cost $[7,8]$. The use of photocatalysts is also an effective method for decomposing the carcinogenic and non-biodegradable dyes $[9,10]$.

Cipta et al. [11] have reported the separation of allophane from the volcanic soil of mount Gamalama volcano. The allophane from the volcanic soil of mount Gamalama is shaped like an irregular ball, with a constituent mineral in the form of silicaalumina and has surface of area $125.158 \mathrm{~m}^{2} \mathrm{~g}^{-1}[11,12]$. Allophane is possible to use as an adsorbent because it has large surface area. The nanocomposite bismuth oxyiodide (BiOI)-allophane from the volcanic soil of mount Gamalama has the ability to absorb visible light [12]. Based on these findings, this study examines the ability of allophane and BiOI-allophane nanocomposite in the removal of methylene blue contaminants. Allophane will be used as an adsorbent in the methylene blue adsorption process while $\mathrm{BiOI}$-allophane nanocomposite as a photocatalyst to decompose methylene blue.

\section{EXPERIMENTAL}

The adsorption process is carried out by adding $50 \mathrm{mg}$ of allophane into various concentration of methylene blue (20, 50, 80, 100 and 200) $\mathrm{ppm}$. The mixture was stirred for $45 \mathrm{~min}$ then separated the solution by using centrifugation. The solution was then measured using UV-visible spectroscopy. $\mathrm{BiOI}$ and nanocomposite $\mathrm{BiOI}-$ allophane are synthesized according to the reported procedures [12]. The photodegradation process was performed using methylene blue with a concentration of $20 \mathrm{ppm}$ with a direct sun radiation time of $45 \mathrm{~min}$. The $\mathrm{pH}$ of solution is allowed to correspond to $\mathrm{pH}$ of methylene blue solution. The results of photodegradation were then measured by UV-visible spectroscopy. 


\section{RESULTS AND DISCUSSION}

Adsorption of methylene blue was performed by using allophane from Gamalama volcanic soil as an adsorbent, while the photodegradation process is carried out using $\mathrm{BiOI}$-allophane composite under direct sunlight for $45 \mathrm{~min}$. Table-1 shows the results of methylene blue adsorption onto allophane, based on variation in initial concentration of methylene blue.

TABLE-1

REMOVAL OF METHYLENE BLUE BY USING ALLOPHANE (VARIOUS METHYLENE BLUE INITIAL CONCENTRATION)

\begin{tabular}{crrr}
\hline $\begin{array}{c}\text { Initial concentration } \\
(\mathrm{ppm})\end{array}$ & \multicolumn{1}{c}{$\mathrm{C}_{\mathrm{e}}(\mathrm{ppm})$} & $\mathrm{C}$ ads. $(\mathrm{ppm})$ & Ads. (\%) \\
\hline 20 & 5.3298153 & 13.4564644 & 73.35092 \\
50 & 10.6068600 & 39.3931398 & 78.78628 \\
80 & 14.3007920 & 65.4353562 & 82.12401 \\
100 & 12.1899740 & 86.8073879 & 87.81003 \\
200 & 77.0976250 & 118.2058050 & 61.45190 \\
\hline
\end{tabular}

It is found that the percentage of adsorption increased when initial concentration increases. The percentage of adsorption then decreased to $61.45 \%$ for an initial concentration of 200 $\mathrm{ppm}$. The decrease in adsorption percentage is due to saturation of the allophane adsorbent.

The effect of contact time on the adsorption of methylene blue by allophane is shown in Table-2. The effect of contact time was tested by adsorption for 10,30, 90,120 and $180 \mathrm{~min}$. The optimum adsorption was shown at contact time of $10 \mathrm{~min}$, i.e. $91.81 \%$. The percentage of adsorption decreased gradually from 30, 90, $120 \mathrm{~min}$ and remained constant at $180 \mathrm{~min}$, respectively at $87.74,85.96,85.70$ and $85.70 \%$. This means that methylene blue adsorption process in allophane occurs quickly followed by a slow desoption process. The adsorption process at contact time $120 \mathrm{~min}$ indicating the occurrence of equilibrium is shown by the constant adsorption percentage $85.70 \%$. The amount of active site on the surface of the adsorbent is proportional to the surface area. When the active site on the surface of the adsorbent has been saturated by a certain amount of adsorbate then the addition of adsorption contact time can no longer increase adsorption and even tend to decrease. By using the adsorption data, adsorption isotherms were determined which resulted in compatibility with Freundlich isotherms. The methylene blue adsorption isotherm graph is shown in Fig. 1 with a value of $\mathrm{R}^{2}=0.99$ which means that the adsorption process takes place on heterogeneous and multilayer surfaces.

The photodegradation of methylene blue using nanocomposite BiOI-allophane showed better results than adsorption. This is showed by the greater percentage of optimum degradation $(99.46 \%)$ (Table-3). Photodegradation process was

\begin{tabular}{cccc}
\multicolumn{4}{c}{ TABLE-2 } \\
\multicolumn{4}{c}{ REMOVAL OF METHYLENE BLUE BY USING } \\
ALLOPHANE (VARIOUS CONTACT TIME) \\
\hline $\begin{array}{c}\text { Contact time } \\
(\mathrm{min})\end{array}$ & $\mathrm{C}_{\mathrm{e}}(\mathrm{ppm})$ & C ads. (ppm) & Ads. $(\%)$ \\
\hline 10 & 8.496042216 & 95.25065963 & 91.81078 \\
30 & 12.717678100 & 91.02902375 & 87.74161 \\
90 & 14.564643800 & 89.18205805 & 85.96134 \\
120 & 14.828496040 & 88.91820580 & 85.70702 \\
180 & 14.828496040 & 88.91820580 & 85.70702 \\
\hline
\end{tabular}

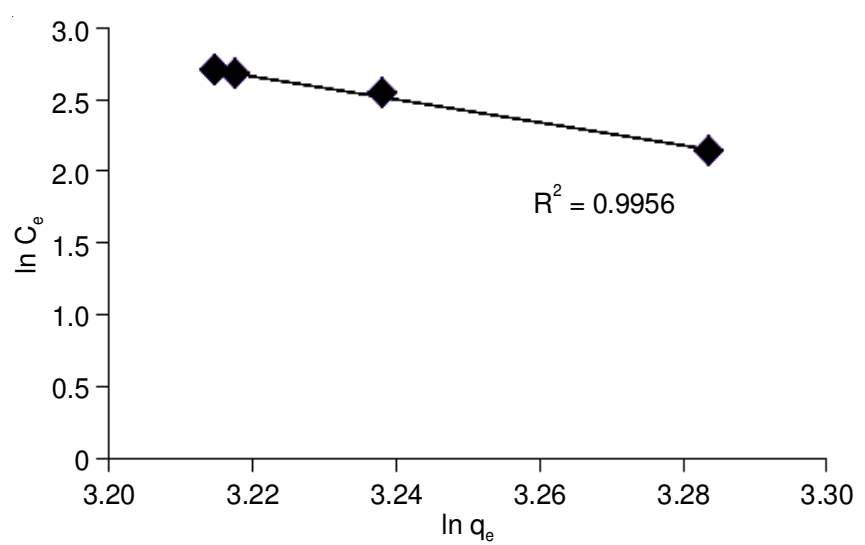

Fig. 1. Freundlich isoterm adsorption

TABLE-3

PHOTODEGRADATIONOF METHYLENE BLUE

\begin{tabular}{lccc}
\multicolumn{1}{c}{ Sample } & $\mathrm{C}_{\mathrm{o}}(\mathrm{ppm})$ & $\mathrm{C}_{\mathrm{e}}(\mathrm{ppm})$ & Degradation $(\%)$ \\
\hline $\mathrm{BiOI}$ & 20 & 0.512928760 & 97.43536 \\
$0.25 \mathrm{~g} \mathrm{Allo} / \mathrm{BiOI}$ & 20 & 0.249076517 & 98.75462 \\
$1.00 \mathrm{~g} \mathrm{Allo} / \mathrm{BiOI}$ & 20 & 0.206860158 & 98.96570 \\
$1.50 \mathrm{~g}$ Allo/BiOI & 20 & 0.106596306 & 99.46702 \\
\hline
\end{tabular}

done only by using direct sunlight for $45 \mathrm{~min}$. The ability of $\mathrm{BiOI}$ to decompose photodegradation increases with increasing amount of allophane in nanocomposite (Fig. 2). The highest photocatalytic ability is shown by the nanocomposite with a total $1.5 \mathrm{~g}$ of allophane $(99.46 \%)$. This is because the presence of allophane increases the nanocomposite surface area. The percentage of photodegradation degradation by $\mathrm{BiOI}$ is lower than that of nanocomposite $\mathrm{BiOI}-$ allophane, which is attributed due to low absorption of $\mathrm{BiOI}$. The presence of allophane enhances the nanocomposite absorption of methylene blue which ultimately increases the ability to degrade methylene blue. The photodegradation mechanism that occurs through two stages i.e., methylene blue adsorption by allophane followed by decomposition by BiOI. The photocatalytic mechanism of $\mathrm{BiOI}$ to decomposed methylene blue under direct sunlight [13] takes place by following equations:

$$
\begin{gathered}
\mathrm{BiOI}+\mathrm{hv} \longrightarrow \mathrm{BiOI}\left(\mathrm{e}^{-}+\mathrm{h}^{+}\right) \\
\mathrm{O}_{2}+\mathrm{e}^{-} \longrightarrow \mathrm{O}_{2}^{\cdot-} \\
\mathrm{O}_{2}^{\bullet-}+\mathrm{e}^{-}+2 \mathrm{H}^{+} \longrightarrow 2^{\bullet} \mathrm{OH}
\end{gathered}
$$

$\mathrm{H}^{+}+\mathrm{O}_{2}{ }^{\cdot-}+{ }^{\bullet} \mathrm{OH}+$ Methylene blue $\longrightarrow \mathrm{CO}_{2}+\mathrm{H}_{2} \mathrm{O}$

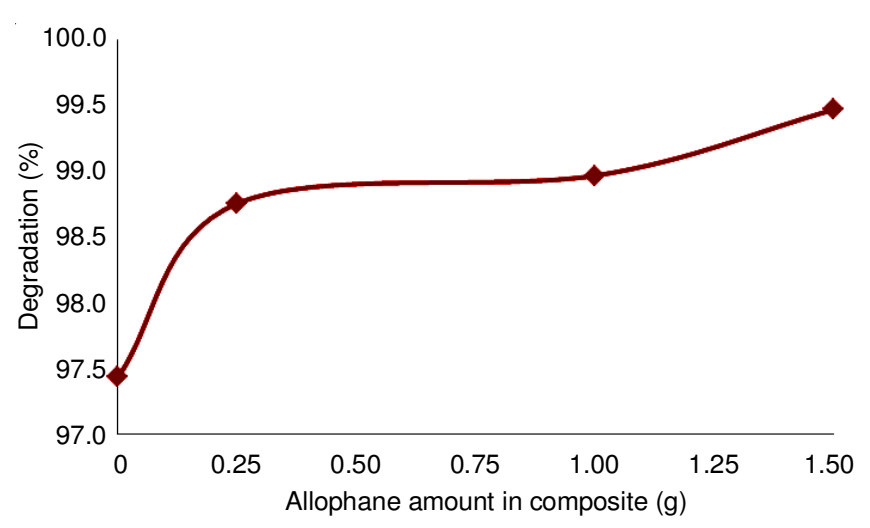

Fig. 2. Effect of amount of allophane on photodegradation of methylene blue 


\section{Conclusion}

Allophane has showed highest methylene blue adsorption $(91.81 \%)$ at initial concentration of $20 \mathrm{ppm}$ and $10 \mathrm{~min}$ contact times. The increase in the initial concentration of methylene blue affects the percentage of adsorption. Nanocomposite BiOI-allophane can work as photocatalysts to decomposed methylene blue under direct sunlight. The highest percentage of degradation (99.46\%) was acheived by nanocomposite BiOI-allophane containing $1.5 \mathrm{~g}$ of allophane.

\section{ACKNOWLEDGEMENTS}

The authors thank the Ministry of Research Technology and Higher Education for funding this research through grants PEKERTI/PKPT 2016-2017.

\section{REFERENCES}

1. M.A.M. Martins, N. Lima, A.J.D. Silvestre and M.J. Queiroz, Chemosphere, 52, 967 (2003);

https://doi.org/10.1016/S0045-6535(03)00286-8.

2. Y.C. Toh, J.J.L. Yen, J.P. Obbard and Y.P. Ting, Enzyme Microb. Technol., 33, 569 (2003); https://doi.org/10.1016/S0141-0229(03)00177-7.
3. Y. Fu and T. Viraraghavan, J. Bioresour. Technol., 79, 251 (2001); https://doi.org/10.1016/S0960-8524(01)00028-1.

4. J. Ma, Y. Jia, Y. Jing, Y. Yao and J. Sun, Dyes Pigments, 93, 1441 (2012); https://doi.org/10.1016/j.dyepig.2011.08.010.

5. M. Toor and B. Jin, Chem. Eng. J., 187, 79 (2012); https://doi.org/10.1016/i.cej.2012.01.089.

6. A. Gürses, S. Karaca, C. Dogar, R. Bayrak, A. Acikyildiz and M. Yalcin, J. Colloid Interface Sci., 269, 310 (2004); https://doi.org/10.1016/j.jcis.2003.09.004.

7. V.K. Gupta and Suhas, J. Environ. Manage., 90, 2313 (2009); https://doi.org/10.1016/j.jenvman.2008.11.017.

8. S.C.R. Santos and R.A.R. Boaventura, Appl. Clay Sci., 42, 137 (2008); https://doi.org/10.1016/j.clay.2008.01.002.

9. A. Fujishima, X. Zhang and D. Tryk, Surf. Sci. Rep., 63, 515 (2008); https://doi.org/10.1016/j.surfrep.2008.10.001.

10. K. Nakata and A. Fujishima, J. Photochem. Photobiol C: Photochem Rev., 13, 169 (2012); https://doi.org/10.1016/j.jphotochemrev.2012.06.001.

11. I. Cipta, N.A. Limatahu, S.H. Nur Abu, I. Kartini and Y. Arryanto, Asian J. Chem., 29, 1702 (2017); https://doi.org/10.14233/ajchem.2017.20620.

12. I. Cipta, N.A. Limatahu, N.A.S. Hayatun, I. Kartini and Y. Arryanto, Asian J. Chem., 29, 1042 (2017); https://doi.org/10.14233/ajchem.2017.20402.

13. L. Ye, Y. Su, X. Jin, H. Xie and C. Zhang, Environ. Sci. Nano, 1, 90 (2014); https://doi.org/10.1039/c3en00098b 